tion of psychological theory to the implementation of evidence based practice. This article was informed by discussions in a seminar series funded by the British Psychological Society (the scientific understanding of the psychological processes involved in the implementation of evidence based practice in health services) and in an advisory group to a programme grant funded by the Medical Research Council (process modelling in implementation research: selecting a theoretical basis for interventions to change practice; MJ, Martin Eccles, Jeremy Grimshaw, Nigel Pitts, Nick Steen).

\section{Competing interests: None declared.}

1 Grimshaw JM, Shirran L, Thomas R, Mowatt G, Fraser C, Bero L, et al Changing provider behaviour: an overview of systematic reviews of interventions. Med Care 2001;39(suppl 2):2-45.

2 Ley P. Communicating with patients. London: Chapman and Hall, 1988.

3 Ley P. Written communication. In: Baum A, Newman S, Weinman J, West R, McManus C, eds. Cambridge handbook of psychology, health and medicine. Cambridge: Cambridge University Press, 1997:331-4.

4 Gollwitzer PM. Implementation intentions: strong effects of simple plans. Am Psychol 1999;54:493-503.

5 Kazdin AE. Behaviour modification in applied settings. Belmont, CA Wadsworth/Thomson Learning, 2001.

6 Grol R, Dalhuijsen J, Thomas S, Veld C, Rutten, G, Mokkink H. Attributes of clinical guidelines that influence use of guidelines in general practice: observational study. BMJ 1998;317:858-61.

7 Grol R. Beliefs and evidence in changing clinical practice. BMJ 1997;315:418-21.

8 National Institute for Clinical Excellence. Schizophrenia: core interventions in the treatment and management of schizophrenia in primary and secondary care. Clinical guideline 1. London: NICE, 2002.

9 Eccles, M. Deriving recommendations in clinical practice guidelines. Qual Saf Health Care (in press).

10 National Institute for Clinical Excellence. CG2-Infection control, prevention of healthcare-associated infection in primary and community care (NICE guideline). www.nice.org.uk/Docref.asp?d = 71777 (accessed 6 Jan 2003).

11 National Institute for Clinical Excellence. CG4 - Head injury: triage, assessment, investigation and early management of head injury in infants, children and adults (NICE guideline). www.nice.org.uk/Docref.asp?d $=74656$ (accessed 6 Jan 2003).

12 National Institute for Clinical Excellence. CG3-Chronic heart failure: management of chronic heart failure in adults in primary and secondary care (NICE guideline) www.nice.org.uk/Docref.asp?d = 79726 (accessed 6 Jan 2003).

13 Cone JD. Issues in functional analysis in behavioural assessment. Behav Res Ther 1997;35:259-75.

14 Kanfer FH, Saslow G. Behavioral diagnosis. In: Franks CM, ed. Behavior therapy: appraisal and status. New York: McGraw-Hill, 1969:417-44.

15 Grady KE, Lemkau JP, Lee NR, Caddell C. Enhancing mammography referral in primary care. Prev Med 1997;26:791-800.

16 Eccles M, Steen N, Grimshaw G, Thomas L, McNamee P, Soutter J, et al. Effect of audit and feedback and educational reminder messages on primary care radiology referrals. Lancet 2001;357, 1406-9.

(Accepted 8 December 2003)

\title{
A memorable patient
}

\section{A nanny's stamina}

When I started as a senior house officer on the unit she was practically mute: the effort of speaking was immense, she could give none of the usual conversational cues, and it was difficult to maintain such a one sided encounter for long. She sat on the ward throughout the day, eschewing the group activities, her face conveying silent despair. "I just can't do anything," she would manage. Later she recalled how she had felt the predicament of others trying to draw her out, but when I asked what she felt her attendants should do in that situation, she replied, "You can't, there's nothing anyone can do. When someone's like that you just have to leave them." None the less, I went every day to see her, asking her how she was and taking blood to check the levels of her various antidepressants.

She disliked taking the tablets, and we kept increasing them. She acquiesced to this with that self contained sense of having to suffer fools gladly that only the Scots can truly master. Of course, she was right, and later we tipped her into mania,

embarrassing her greatly at the things she then said. To begin with, as the drugs slowly took effect, she began to fret about her hair, which by then needed washing, and the time she needed to get ready in the morning. But then, majestic in intricate cardigans, she took up her knitting, and as she emerged so did part of her story, or that part of an era when she had been in control.

The notes gave the long history of her manic depressive illness and described her as an "ex-nanny." Feeling at the time that I was having more than my fair share of nanny troubles, I was interested in her as a relic from a time when nannies seemed to me to have been real nannies. This encouraged her. She spoke of coming down from Scotland to the south coast of England with her employers to look after their four children. She described the large house, trimmed hedges, her uniform, and the mother who dressed elegantly to receive and visit friends for lunch. She recounted her day off each week, the long hours, and the evenings spent starching and pressing the children's clothes. Of course, she had an under-nanny to help her with this, but, she intimated, young girls these days didn't know their luck.

From my experience, I tended to agree, but this domestic scene was later shattered. One day in this household she had been unwell with a fever heralding pneumonia. The mother, pregnant with her fifth child, had visited the nursery, and the children had reported that Nanny was unwell. "No she isn't. She's just pretending," the mother had replied.

Nanny had bit her lip, finished her day's work, and later confronted the mother with the news that she was leaving. "You should not have talked to me like that in front of the children," she said.

The children cried all that night, and in the morning the mother was contrite. She had not really meant it. "How am I to cope with this next baby?" she wailed.

"You should have thought of that in the first place," came Nanny's retort. Off she sailed without references to land another job in no time.

Back on the ward, she smiled a sad resigned smile. The stamina that kept her through the ups and downs of her current illness was part of the same strength of character that earlier meant she had not been able to know her place.

Elizabeth Davies senior clinical research fellow, London

We welcome articles up to 600 words on topics such as A memorable patient, A paper that changed my practice, My most unfortunate mistake, or any other piece conveying instruction, pathos, or humour. Please submit the article on http://sdubmit.bmj.com Permission is needed from the patient or a relative if an identifiable patient is referred to. We also welcome contributions for "Endpieces," consisting of quotations of up to 80 words (but most are considerably shorter) from any source, ancient or modern, which have appealed to the reader. 